\title{
Occupational Stress and Perceived Quality of Life Among Clinical Nurses: A Cross-Sectional Study in A Nigerian State
}

Olufemi Oyebanji Oyediran', Oreoluwa Ruth Oloyede ${ }^{2}$, Emmanuel O. Ayandiran $^{3}$, Matthew Idowu Olatubi ${ }^{4}$ and Funmilola Adenike Faremi ${ }^{5}$

\begin{abstract}
This study assessed the influence of occupational stress on perceived quality of life among clinical nurses in selected hospitals in Nigeria.

A cross sectional descriptive research design was adopted while multiple sampling was used to select the respondents from hospitals in Ogun state. Slovin's formula $\left(n=N /\left[1+N\left(e^{2}\right)\right]\right)$ was used to determine the sample size of 425 . A structured questionnaire was used to obtain information from respondents. The analysis was done with SPSS version 25 while descriptive such as tables and bar charts and inferential statistics were used to present the data.

Findings revealed that the mean age of the respondents is $36.37 \pm 8.90$ years and majority of the respondents were between 30-49 years. Almost half of the respondents $(48.0 \%)$ reported high occupational stress while $44.2 \%$ and $7.8 \%$ reported low \& fair occupational stress respectively. High workload (83.9\%), long hours of night shift (71.1\%), lack of resources and equipment (67.8\%), frequency night shift $(67.5 \%)$, emotional load of dealing with aggressive and demanding patients $(62.6 \%)$, poor salary (61.6\%), and prolong standing with no time for break $(58.5 \%)$ are factors responsible for stress among nurses. The results further showed that $52.2 \%$ of the respondents reported good work-related quality of life while $38.8 \%$ rated their work-related quality of life as poor. The study also showed that

\footnotetext{
1 Department of Nursing Science, Obafemi Awolowo University, Ile-Ife, Nigeria.

2 School of Midwifery Ijebuode Ogun State, Nigeria.

3 Department of Nursing Science, Obafemi Awolowo University, Ile-Ife, Nigeria.

${ }^{4}$ Department of Nursing Science, Bowen University, Iwo, Nigeria.

5 Department of Nursing Science, Obafemi Awolowo University, Ile-Ife, Nigeria.
}

Article Info: Received: December 4, 2021. Revised: December 23, 2021.

Published online: January 10, 2022. 
there was significant relationship between occupational stress (Organizational issues $(\mathrm{P}=\mathbf{0 . 0 3 5})$, Occupational hazards $(\mathrm{P}=\mathbf{0 . 0 2 4})$, Interpersonal relationships $(\mathrm{p}=$ 0.003) and unmet basic physiological needs $(\mathrm{P}=\mathbf{0 . 0 0 5})$ ) and work-related quality of life.

Conclusion: This study concluded that occupational stress affects nurses' workrelated quality of life negatively and influence patients' outcomes. Hence, there is an urgent need for development of health promotion programmes on stress reduction and stress management.

Keywords: Influence, Occupational Stress, Quality of life, Clinical Nurses.

\section{Introduction}

The highly demanding nature of work experienced by nursing professionals makes it one of the most stressful professions. The stressful nature of the nursing profession requires them to possess high physical and emotional resilience to tackle work-related issues so they can perform better at work [1]. Healthcare professionals face situations of intense psychological and emotional involvement in daily practice [2].

Repeated contact with the suffering of patients and organisational aspects of their work context are considered risk factors affecting the psychological and emotional well-being of workers [3]. This scenario causes professionals to find themselves in situations of vulnerability that may be conducive to the development of various mental conditions (stress, anxiety, fatigue, exhaustion) related to burnout syndrome and compassion fatigue. Both syndromes have a direct, negative impact on health professionals' quality of life, well-being and perceived health [4]. On the other hand, a positive aspect arising from helping patients is compassion satisfaction, the rewarding feeling that professionals experience when caring for others which encourages them to continue to do so [5].

Exposure to stressors at work and lack of adequate coping resources may affect health professionals' mental or physical health. This results in reduced quality of life which, in turn, results in a reduction in the quality of patient care. According to the existing literature, several components have been assessed and classified as unfavourable by professionals, indicating that they may have consequences for the professionals' perception of their quality of life [6]. These components include characteristics of their work environment (shift, employment status, setting), workrelated stress, and sociodemographic factors affecting them, such as age, marital status, years of work experience and particularly gender [7]. Women's health and emotional well-being may be more severely affected than men's, as work on their jobs may be compounded by household chores and family care [8]. In this sense, it is nursing professionals who are the most fragile and have a high risk of having their quality of life affected by the characteristics of their work. Their work environment and their experiences with patients negatively affect nurses' quality of life $[9,10]$. Occupational stress is a recognized health problem among nurses. Occupational 
stress detracts from nurses' quality of life and efficiency of job performance [11]. Globally, its prevalence among nurses varies widely between $9.2 \%$ and $68.0 \%$ [12]. An overall pooled prevalence of stress symptoms among global nurses was $11.23 \%$. Significant differences were noted between geographical regions, specialties and type of measurement used. Sub-Saharan African region had the highest stress symptoms prevalence rate while Europe and Central Asia region had the lowest. Paediatric nurses had the highest stress symptoms prevalence rates among all specialties while Geriatric care nurses had the lowest [13]. However, results relating to National health service staffs' health and wellbeing have continued to worsen. In $2019,44 \%$ of registered nurses and midwives said they had felt unwell due to stress in the past year up from $43.5 \%$ in 2018 and $41.1 \%$ in 2015 [14].

Stress prevalence data on nurses worldwide is growing. In 2017, a meta-analytic study evaluated studies on nurses' stress found that stress prevalence in nursing professionals (total sample of nurses, $\mathrm{n}=1566$ ) was $31 \%$ for emotional exhaustion, $36 \%$ for depersonalization, and $29 \%$ for low personal accomplishment [15]. A recent systematic review and analysis of studies on stress among nurses $(\mathrm{n}=1110$ nurses) showed that the prevalence of stress was $28 \%$ for high emotional exhaustion, $15 \%$ for high depersonalization, while $31 \%$ for low personal accomplishment among the nurses [16].

There have been several attempts at quantifying the burden of stress. Nursing practitioners in Nigerian healthcare settings experience workplace stress and sociodemographic factors such as sex, age, work environment, and work experience could be correlated to work-related stress and stress among professionals in medical settings $[17,18]$. Research further indicates that nursing professionals operate in complex workplaces wherein they encounter life-threatening diseases, intricate patient and family circumstances, and individuals in high distress. Many nurses are also overworked, under-resourced, undertrained, inadequately supervised, and undervalued. These issues, as indicated by some researchers, often result in workrelated stress among nursing professionals [19].

This is more so because nurses are expected to deliver humane, empathetic, culturally sensitive, proficient and moral care, in working environments with limited resources, reduced supply of nurses and increasing responsibilities. Such imbalance between providing high quality care within an environment of limited resources leads to stress and equally affect the quality of life among nurses [20]. Hence, this study determined the level of occupational stress among nurses, identified factors responsible for stress among nurses, determined the work-related quality of life of nurses and also determined the influence of occupational stress on perceived quality of life among nurses.

\section{Materials and Methods}

The study adopted a descriptive, non-experimental design, to determine the influence of stress on perceived quality of life among nurses in selected hospitals in Ogun State. 
The research was conducted in selected tertiary hospitals in Ogun state, Southwestern Nigeria. The selected hospitals are Federal Medical Centre (FMC) Abeokuta, Olabisi Onabanjo University Teaching Hospital (OOUTH) is situated at Sagamu and Babcock University Teaching Hospital (BUTH).

A convenience sampling technique was used to select nurses working in various units and wards of the selected hospitals in Ogun state. The total population of nurses working at FMC is 400, OOUTH is 120 and BUTH is 200 and a sample size of 425 was calculated using Slovin's formula.

A structured questionnaire was used for data collection. The questionnaires are in five sections which are sections A, B, C, D and E as follows:

Section A assessed respondents' socio-demographic variables. Section B was a 43 item with 4-point Likert scale (1 to 4 representing "strongly disagree" to "strongly agree") adapted from Nurses' Occupational Stressor Scale (NOSS) designed to measure level of occupational stress among nurses. The subscales include the following (1) Work conflicts (6 items with score range 0-24); (2) Work-family conflicts (5 items with score range 0-20); (3) Insufficient support from co-workers or care-givers (5 items with score range $0-20$ ); (4) Workplace violence and bullying (4 items with score range 0-16); (5) Organizational issues (5 items with score range 0-20); (6) Occupational hazards (5 items with score range 0-20); (7) Difficulty taking leave (2 items with score range 0-8); (8) Powerlessness (3 items with score range 0-12); (9) Interpersonal relationships (5 items with score range 0-20); (10) Unmet basic physiological needs (3 items with score range 0-12). A total (range 0172) score is derived from the instrument using subscale scores which was converted to percentage, $>70 \%$ is high, $50 \%-70 \%$ score is moderate while less than $50 \%$ indicate low level of occupational stress.

Section $\mathrm{C}$ had 8 items with Yes or No option that identified factors influencing stress among nurses. Section D: a 35 item 4-point Likert scale (1 to 4 representing "strongly disagree" to "strongly agree") adapted from Quality of Nursing Work Life Survey (QNWL) that was developed by Beth A. Brooks in USA in 2001 to determine work related quality of life among nurses. The subscales include Work Environment (8 items with score range 0-32); Relations with managers (5 items with score range $0-20$ ); Work conditions (10 items with score range 0-40); Job perception (7 items with score range 0-28); Support services (4 items with score range 0-16). A total (range 0-136) score is derived from the instrument using subscale scores which was converted to percentage. Score $>70 \%$ was categorized as high, $50 \%-70 \%$ score is average while less than $50 \%$ was categorized as low quality of life.

Section E had 11 items that determined the influence of stress on perceived quality of life. It is measured on 4 Likert scale: Strongly Disagree (SD) -1, Disagree (D)-2 Agree (A)-3, Strongly Agree (SA)-4 which measured on a score between 0-44 and was converted to percentage, $>70 \%$ is good, $50 \%-70 \%$ score is fair while less than $50 \%$ is poor influence.

Administration of the questionnaire was done during working days for a period of 3 weeks. Copies of questionnaires were given to the respondents after explaining the purpose 
of the study to them. Data was analysed using computer Software Statistical Package for the Social Sciences [SPSS] version 25. Descriptive statistics such as tables, bar charts were described in terms of frequency and percentage. Inferential statistics like chi square and multiple regression were used to determine the relationship between variables. The level of significance was set as 0.05 for accepting or rejecting the research hypotheses.

Respondents' informed consent was obtained and they were assured of the confidentiality of the information supplied, also anonymity as well as voluntary withdrawal was ensured. The study proposal was approved by the Ethical Committee with approval number- OOUTH/HREC/398/2020AP.

\section{Results}

A total of four hundred and twenty-five (425) questionnaires were distributed among nurses in Ogun State while a total number of four hundred and twenty-three (423) questionnaires were retrieved and same were presented in the result section. 
Table 1: Socio-demographic Characteristics of Respondents

\begin{tabular}{|c|c|c|}
\hline Variables & Frequency $(n=423)$ & Percentage $(\%)$ \\
\hline $\begin{array}{l}\text { Age: } \text { Mean= 36.37 } \pm 8.90, \text { Min= 17, } \text { Max }=64 \\
20-29 \\
30-39 \\
40-49 \\
50-59 \\
60 \text { and above }\end{array}$ & $\begin{array}{c}122 \\
118 \\
164 \\
18 \\
1\end{array}$ & $\begin{array}{r}28.8 \\
27.9 \\
38.8 \\
4.3 \\
0.2\end{array}$ \\
\hline $\begin{array}{l}\text { Sex } \\
\text { Male } \\
\text { Female }\end{array}$ & $\begin{array}{c}121 \\
302\end{array}$ & $\begin{array}{l}28.6 \\
71.4\end{array}$ \\
\hline $\begin{array}{l}\text { Marital status } \\
\text { Single } \\
\text { Married } \\
\text { Divorced } \\
\end{array}$ & $\begin{array}{r}119 \\
298 \\
6\end{array}$ & $\begin{array}{r}28.1 \\
70.5 \\
1.4\end{array}$ \\
\hline $\begin{array}{l}\text { Professional qualification } \\
\text { RN only } \\
\text { RN/RM }\end{array}$ & $\begin{array}{l}117 \\
246 \\
\end{array}$ & \\
\hline $\begin{array}{l}\text { Educational qualification } \\
\text { Diploma } \\
\text { BNSc } \\
\text { BSc } \\
\text { Msc } \\
\text { PhD }\end{array}$ & $\begin{array}{c}71 \\
126 \\
166 \\
31 \\
29\end{array}$ & $\begin{array}{l}16.7 \\
29.8 \\
39.2 \\
7.3 \\
6.9\end{array}$ \\
\hline $\begin{array}{l}\text { Year of Practice: Mean }=\mathbf{1 0 . 3 1} \pm \mathbf{8 . 0 3} \\
1-10 \\
11-20 \\
21-30 \\
31 \text { and above }\end{array}$ & $\begin{array}{l}19 \\
34 \\
64 \\
58\end{array}$ & $\begin{array}{l}10.9 \\
19.4 \\
36.6 \\
33.1\end{array}$ \\
\hline $\begin{array}{l}\text { Current rank } \\
\text { NO II } \\
\text { NO1 } \\
\text { SNO } \\
\text { PNO } \\
\text { ACNO } \\
\text { CNO }\end{array}$ & $\begin{array}{c}78 \\
62 \\
73 \\
34 \\
144 \\
32\end{array}$ & $\begin{array}{c}18,4 \\
14.7 \\
17.3 \\
8.0 \\
34.0 \\
7.6\end{array}$ \\
\hline
\end{tabular}

The table above reveals the socio-demographic distribution of the respondents. Majority of the respondents $(38.8 \%)$ were between $40-49$ years with a mean of 36.37 \pm 8.90 . more than two third $71.4 \%$ were female and $28.6 \%$ were male, $70.5 \%$ were married, more than half $58.2 \%$ had RN/RM, 39.2\% were BNSC holder, $36.6 \%$ had practices between $21-30$ years and $34.0 \%$ were ACNO. 
Table 2: Occupational Stress among Nurses

\begin{tabular}{|c|c|c|c|c|}
\hline Variables $(\mathrm{N}=423)$ & SD & $\mathbf{D}$ & $\mathbf{A}$ & SA \\
\hline $\begin{array}{l}\text { Work Demands } \\
\text { I am worried about receiving complaints from } \\
\text { patients or their relatives for not meeting their } \\
\text { demands }\end{array}$ & $281(66.6)$ & $48(11.4)$ & $61(14.5)$ & $32(7.6)$ \\
\hline $\begin{array}{l}\text { I have to bear the negative sentiment of patients or } \\
\text { their relatives. }\end{array}$ & $150(35.5)$ & $149(35.3)$ & $102(24.2)$ & $21(5)$ \\
\hline $\begin{array}{l}\text { I do not have sufficient time to meet patients' and } \\
\text { their relatives' demands. }\end{array}$ & $139(32.9)$ & $96(22.7)$ & $150(35.5)$ & $37(8.8)$ \\
\hline $\begin{array}{l}\text { I am unsure of the extent of patients' conditions or } \\
\text { treatments that I should reveal to them }\end{array}$ & $106(25.1)$ & $123(29.1)$ & $105(24.9)$ & $88(20.9)$ \\
\hline $\begin{array}{l}\text { Excessive duties in the workplace prevent me from } \\
\text { attending to patients. }\end{array}$ & $99(23.5)$ & $87(20.6)$ & $151(35.8)$ & $85(20.1)$ \\
\hline $\begin{array}{l}\text { I have to maintain professional units other than my } \\
\text { own }\end{array}$ & $84(19.9)$ & $88(20.9)$ & $115(27.3)$ & $135(32)$ \\
\hline $\begin{array}{l}\text { Work-Family Conflict } \\
\text { The burden of work affects my domestic life. }\end{array}$ & $230(54.5)$ & $65(15.4)$ & $73(17.3)$ & $54(12.8)$ \\
\hline $\begin{array}{l}\text { The amount of time my job occupies makes it } \\
\text { difficult for me to fulfil family responsibilities. }\end{array}$ & $124(29.4)$ & $150(35.5)$ & $105(24.9)$ & $43(10.2)$ \\
\hline $\begin{array}{l}\text { The burden of work makes it difficult for me to } \\
\text { undertake my personal chores and/or engage in } \\
\text { hobbies. }\end{array}$ & $97(23)$ & $100(23.7)$ & $118(28)$ & $107(25.4)$ \\
\hline $\begin{array}{l}\text { My job produces strain that makes it difficult for me } \\
\text { to fulfil my family duties }\end{array}$ & $174(41.2)$ & $79(18.7)$ & $116(27.5)$ & $53(12.6)$ \\
\hline $\begin{array}{l}\text { I have to adapt my schedule for family } \\
\text { activities/outings to accommodate my work } \\
\text { responsibilities. }\end{array}$ & $112(26.5)$ & $110(26.1)$ & $113(26.8)$ & $87(20.6)$ \\
\hline $\begin{array}{l}\text { Insufficient Support from Co-workers or } \\
\text { Caregivers } \\
\text { The professional evaluation of care of mine is } \\
\text { opposite to that of the doctors. }\end{array}$ & $208(49.3)$ & $109(25.8)$ & $69(16.4)$ & $36(8.5)$ \\
\hline Doctors' temperamental nature agitates me. & $170(40.3)$ & $109(25.8)$ & $112(26.5)$ & $31(7.3)$ \\
\hline $\begin{array}{l}\text { I cannot instantaneously obtain patient-related } \\
\text { information because of inadequate communication } \\
\text { within the team }\end{array}$ & $137(32.5)$ & $128(30.3)$ & $123(29.1)$ & $34(8.1)$ \\
\hline $\begin{array}{l}\text { Team members do not appear to help in a timely } \\
\text { manner under urgent circumstances }\end{array}$ & $100(23.7)$ & $136(32.2)$ & $138(32.7)$ & $48(11.4)$ \\
\hline $\begin{array}{l}\text { Lack of support from the team affects patients' trust } \\
\text { in me. }\end{array}$ & $83(19.7)$ & $101(23.9)$ & $135(32)$ & $103(24.4)$ \\
\hline $\begin{array}{l}\text { Workplace Violence and Bullying } \\
\text { Verbal abuse such as insults and sarcastic comments. }\end{array}$ & $180(42.7)$ & $76(18)$ & $96(22.7)$ & $70(16.6)$ \\
\hline $\begin{array}{l}\text { Psychological abuse such as threats, discrimination, } \\
\text { bullying, and harassment. }\end{array}$ & $186(44.1)$ & $107(25.4)$ & $80(19)$ & $49(11.6)$ \\
\hline $\begin{array}{l}\text { Physical abuse such as hitting, kicking, pushing, } \\
\text { pinching, pulling, and dragging. }\end{array}$ & $148(35.1)$ & $114(27)$ & $91(21.6)$ & $69(16.4)$ \\
\hline
\end{tabular}




\begin{tabular}{|c|c|c|c|c|}
\hline $\begin{array}{l}\text { Sexual harassment such as inappropriate } \\
\text { implications and behaviours. }\end{array}$ & $185(43.8)$ & $81(19.2)$ & $107(25.4)$ & $49(11.6)$ \\
\hline $\begin{array}{l}\text { Organizational Issues } \\
\text { The on-call system affects my life. }\end{array}$ & $159(37.7)$ & $109(25.8)$ & $100(23.7)$ & $54(12.8)$ \\
\hline My working hours include on-call hours. & $141(33.4)$ & $103(24.4)$ & 141(33.4) & $37(8.8)$ \\
\hline $\begin{array}{l}\text { I was informed of a change to my schedule at less } \\
\text { than } 24 \text { hours' notice. }\end{array}$ & $99(23.5)$ & $150(35.5)$ & $121(28.7)$ & $52(12.3)$ \\
\hline $\begin{array}{l}\text { The organization usually remunerates my overtime } \\
\text { work at a low rate of pay. }\end{array}$ & $78(18.5)$ & $152(36)$ & $134(31.8)$ & $58(13.7)$ \\
\hline $\begin{array}{l}\text { Not achieving a promotion (e.g., level } 1 \text { or } 2 \text { ) within } \\
\text { the expected period affects my income. }\end{array}$ & $185(43.8)$ & $81(19.2)$ & $107(25.4)$ & $49(11.6)$ \\
\hline $\begin{array}{l}\text { Occupational Hazards } \\
\text { Exposure to chemicals such as chemotherapy drugs, } \\
\text { alcohol, and Cidex. }\end{array}$ & $159(37.7)$ & $109(25.8)$ & $100(23.7)$ & $54(12.8)$ \\
\hline $\begin{array}{l}\text { Exposure to radiation or strong light such as X-ray, } \\
\text { ultraviolet light, and lasers. }\end{array}$ & $141(33.4)$ & $103(24.4)$ & $141(33.4)$ & $37(8.8)$ \\
\hline $\begin{array}{l}\text { I feel stressed considering that my patients might be } \\
\text { have contagious diseases such as ARS or AIDS }\end{array}$ & $150(35.5)$ & $149(35.3)$ & $102(24.2)$ & $21(5)$ \\
\hline Transporting patients or equipment. & $139(32.9)$ & $96(22.7)$ & $150(35.5)$ & $37(8.8)$ \\
\hline $\begin{array}{l}\text { The workplace offers sufficient protective } \\
\text { equipment such as masks and gowns. }\end{array}$ & $106(25.1)$ & $123(29.1)$ & $105(24.9)$ & $88(20.9)$ \\
\hline $\begin{array}{l}\text { Difficulty Taking Leave }(0 \%=\text { very difficult, } 100 \% \\
=\text { very smooth) } \\
\text { The level of difficulty in asking for leaves for } \\
\text { household emergencies is } \%\end{array}$ & $99(23.5)$ & $87(20.6)$ & $151(35.8)$ & $85(20.1)$ \\
\hline $\begin{array}{l}\text { The level of difficulty in excusing myself for feeling } \\
\text { strong discomfort is }\end{array}$ & $84(19.9)$ & $88(20.9)$ & $115(27.3)$ & $135(32)$ \\
\hline $\begin{array}{l}\text { Powerlessness } \\
\text { Patients' conditions do not improve. }\end{array}$ & $230(54.5)$ & $65(15.4)$ & $73(17.3)$ & $54(12.8)$ \\
\hline Encountering the death of a patient. & $124(29.4)$ & $150(35.5)$ & $105(24.9)$ & $43(10.2)$ \\
\hline $\begin{array}{l}\text { I have insufficient time to offer mental health care to } \\
\text { patients during working hours. }\end{array}$ & $97(23)$ & $100(23.7)$ & $118(28)$ & $107(25.4)$ \\
\hline $\begin{array}{l}\text { Interpersonal Relationships } \\
\text { Relationships among colleagues within the unit are } \\
\text { generally good. }\end{array}$ & $174(41.2)$ & $79(18.7)$ & $116(27.5)$ & $53(12.6)$ \\
\hline $\begin{array}{l}\text { I should teach student nurses and newcomers while } \\
\text { caring for patients. }\end{array}$ & $112(26.5)$ & $110(26.1)$ & $113(26.8)$ & $87(20.6)$ \\
\hline $\begin{array}{l}\text { I worry that my colleagues' incompetence will affect } \\
\text { patient safety. }\end{array}$ & $150(35.5)$ & $149(35.3)$ & $102(24.2)$ & $21(5)$ \\
\hline $\begin{array}{l}\text { The manager or head nurse supports me in the event } \\
\text { of a conflict between me and a patient. }\end{array}$ & 139(32.9) & $96(22.7)$ & $150(35.5)$ & $37(8.8)$ \\
\hline $\begin{array}{l}\text { Primary caregivers do not execute their tasks } \\
\text { appropriately. }\end{array}$ & $106(25.1)$ & $123(29.1)$ & $105(24.9)$ & $88(20.9)$ \\
\hline
\end{tabular}




\begin{tabular}{|l|c|c|c|c|}
\hline $\begin{array}{l}\text { Unmet Basic Physiological Needs } \\
\text { I have no time to fulfil my personal needs (e.g., water } \\
\text { consumption and toilet breaks). }\end{array}$ & $99(23.5)$ & $87(20.6)$ & $151(35.8)$ & $85(20.1)$ \\
\hline $\begin{array}{l}\text { I cannot take an uninterrupted 30-minute mealtime } \\
\text { break. }\end{array}$ & $36(8.5)$ & $114(27)$ & $188(44.5)$ & $84(19.9)$ \\
\hline $\begin{array}{l}\text { I can receive deserved compensation such as } \\
\text { premiums and compensatory leave for overtime of } \\
\text { more than one hour. }\end{array}$ & $27(6.4)$ & $114(27)$ & $168(39.8)$ & $113(26.8)$ \\
\hline
\end{tabular}

The table above reveals occupational stress among Nurses. More than two third $(66.6 \%)$ of the respondents were not worried about receiving complaints from patients or their relatives for not meeting their demands, 35.5\% didn't bear any negative sentiment of patients or their relatives, $35.8 \%$ agree that excessive duties in the workplace prevent me them attending to patients, $32.0 \%$ strongly agree that they maintain professional units other than my own, 35.5\% disagree that the amount of time their job occupies makes it difficult for me to fulfil family responsibilities, $26.8 \%$ agree that they adapt my schedule for family activities/outings to accommodate my work responsibilities, $49.3 \%$ strongly disagree that professional evaluation of care of theirs is opposite to that of the doctors and $7.3 \%$ strongly agree that the doctors' temperamental nature agitates them.

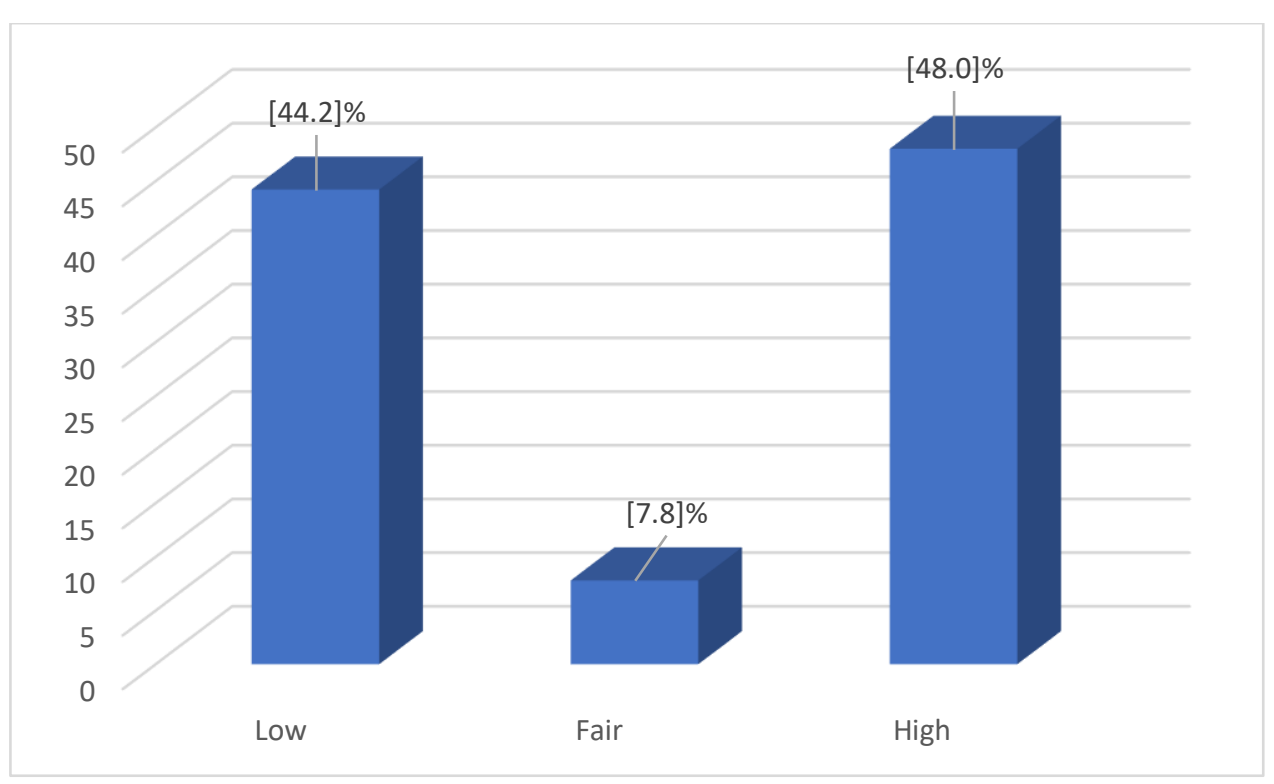

Figure 1: Summary of Occupational Stress among Clinical Nurses

The figure shows a summary of occupational stress. The result showed that more than one third of the respondents $(48.0 \%)$ claim that the work stress is high, $44.2 \%$ low and $7.8 \%$ claim is fair. 
Table 3: Factors Responsible for Stress among Nurses

\begin{tabular}{|l|l|c|c|}
\hline S/N & Variables $(\mathbf{N}=423)$ & Yes & No \\
\hline 1. & High workload is a source of stress. & $354(83.9)$ & $68(16.1)$ \\
\hline 2. & $\begin{array}{l}\text { Prolong standing and no time for break is a reason for } \\
\text { stress }\end{array}$ & $247(58.5)$ & $175(41.5)$ \\
\hline 3. & $\begin{array}{l}\text { The emotional load of dealing with aggressive and } \\
\text { demanding patients and their families causes stress }\end{array}$ & $264(62.6)$ & $158(37.4)$ \\
\hline 4. & Shortage of staffs is the reason for stress & $225(53.3)$ & $197(46.7)$ \\
\hline 5. & $\begin{array}{l}\text { Lack of support/motivation from supervisors/ward } \\
\text { managers }\end{array}$ & $240(56.9)$ & $182(43.1)$ \\
\hline 6. & Conflict with nurses and other medical staffs & $218(51.7)$ & $204(48.3)$ \\
\hline 7. & Unexpected death of patient is a cause of stress & $228(54)$ & $194(46)$ \\
\hline 8 & Poor salary that cannot meet family demands & $260(61.6)$ & $162(38.4)$ \\
\hline 9 & Long hours of night shift & $300(71.1)$ & $122(28.9)$ \\
\hline 10 & Frequency night shift & $285(67.5)$ & $137(32.5)$ \\
\hline 11. & Lack of resources and equipment are sources of stress & $286(67.8)$ & $136(32.2)$ \\
\hline
\end{tabular}

The table above presents factors responsible for stress among nurses. The table itemized eleven factors of which all was negated by most the respondents conversely few respondents also agreed with. Majorly high workload is a source of stress, prolong standing and no time for break is a reason for stress, emotional load of dealing with aggressive and demanding patients and their families causes stress, shortage of staffs is the reason for stress, lack of support/motivation from supervisors/ward managers, conflict with nurses and other medical staffs, unexpected death of patient is a cause of stress, poor salary that cannot meet family demands, long hours of night shift, Frequency night shift and lack of resources and equipment are sources of stress. 
Table 4: Work Related Quality of Life Scale of Nurses

\begin{tabular}{|c|c|c|c|c|}
\hline Variables $(\mathrm{N}=423)$ & SD & $\mathbf{D}$ & $\mathbf{A}$ & $\mathbf{S A}$ \\
\hline $\begin{array}{c}\text { Work Environment } \\
\text { Society has positive opinion about nurses. }\end{array}$ & $222(52.6)$ & $80(19)$ & $69(16.4)$ & $51(12.1)$ \\
\hline Institution gives professional opportunities & 143(33.9) & $134(31.8)$ & $114(27)$ & $31(7.3)$ \\
\hline $\begin{array}{l}\text { I communicate with other team members like } \\
\text { Physiotherapist and respiration therapist }\end{array}$ & $117(27.7)$ & $107(25.4)$ & $164(38.9)$ & $34(8.1)$ \\
\hline $\begin{array}{l}\text { I receive support for in-service training and } \\
\text { constant education }\end{array}$ & $98(23.2)$ & $127(30.1)$ & $154(36.5)$ & $43(10.2)$ \\
\hline $\begin{array}{l}\text { Nursing policies and procedures facilitates my } \\
\text { job }\end{array}$ & $92(21.8)$ & $117(27.7)$ & $123(29.1)$ & $90(21.3)$ \\
\hline Safety provides a safe environment & $84(19.9)$ & $118(28)$ & $125(29.6)$ & $95(22.5)$ \\
\hline $\begin{array}{l}\text { I feel safe protected against damage (physical, } \\
\text { moral, verbal) }\end{array}$ & $77(18.2)$ & $110(26.1)$ & $138(32.7)$ & $97(23)$ \\
\hline I believe my job is safe. & $94(22.3)$ & $88(20.9)$ & $137(32.5)$ & $103(24.4)$ \\
\hline Managers respect nursing & $138(32.7)$ & $84(19.9)$ & $102(24.2)$ & $98(23.2)$ \\
\hline $\begin{array}{l}\text { Relations with Managers } \\
\text { I have good communication with my } \\
\text { manager/supervisor nurse. }\end{array}$ & $168(39.8)$ & $86(20.4)$ & $121(28.7)$ & $47(11.1)$ \\
\hline $\begin{array}{l}\text { Manager/supervisor provides adequate } \\
\text { supervision/inspection. }\end{array}$ & $114(27)$ & $136(32.2)$ & $135(32)$ & $37(8.8)$ \\
\hline $\begin{array}{l}\text { Manager/supervisor provides feedback about } \\
\text { performance }\end{array}$ & $83(19.7)$ & $108(25.6)$ & $174(41.2)$ & $57(13.5)$ \\
\hline Manager/supervisor ask our opinions & $68(16.1)$ & $99(23.5)$ & $167(39.6)$ & $88(20.9)$ \\
\hline $\begin{array}{l}\text { My achievements are recognized by } \\
\text { manager/supervisor }\end{array}$ & $103(24.4)$ & $81(19.2)$ & $150(35.5)$ & $88(20.9)$ \\
\hline $\begin{array}{l}\text { Work Conditions } \\
\text { I am overworked }\end{array}$ & $143(33.9)$ & $88(20.9)$ & $131(31)$ & $60(14.2)$ \\
\hline $\begin{array}{l}\text { I can manage a good balance between work and } \\
\text { family. }\end{array}$ & $89(21.1)$ & $92(21.8)$ & $164(38.9)$ & $77(18.2)$ \\
\hline I do a lot of work irrelevant to nursing & $87(20.6)$ & $89(21.1)$ & $135(32)$ & $111(26.3)$ \\
\hline I have energy outside of work & $193(45.7)$ & $81(19.2)$ & $98(23.2)$ & $50(11.8)$ \\
\hline My daily affairs are frequently disrupted. & $151(35.8)$ & $106(25.1)$ & $122(28.9)$ & $43(10.2)$ \\
\hline I have enough time for work & $101(23.9)$ & $142(33.6)$ & $136(32.2)$ & $43(10.2)$ \\
\hline The number of nurses is adequate in my unit. & $72(17.1)$ & $131(31)$ & $153(36.3)$ & $66(15.6)$ \\
\hline Shift work negatively affects my life & $73(17.3)$ & $120(28.4)$ & $144(34.1)$ & $85(20.1)$ \\
\hline My salary is adequate for my job. & $69(16.4)$ & $132(31.3)$ & $136(32.2)$ & $85(20.1)$ \\
\hline $\begin{array}{l}\text { Institutional policy is suitable for saving time for } \\
\text { family. }\end{array}$ & $97(23)$ & $92(21.8)$ & $113(26.8)$ & $120(28.4)$ \\
\hline $\begin{array}{l}\text { Job Perception } \\
\text { I am pleased with my work }\end{array}$ & $185(43.8)$ & $81(19.2)$ & $107(25.4)$ & $49(11.6)$ \\
\hline I have autonomy in deciding patient care & $159(37.7)$ & $109(25.8)$ & $100(23.7)$ & $54(12.8)$ \\
\hline Team work is present in my unit. & $141(33.4)$ & $103(24.4)$ & $141(33.4)$ & $37(8.8)$ \\
\hline I feel attached to work. & $99(23.5)$ & $150(35.5)$ & $121(28.7)$ & $52(12.3)$ \\
\hline I feel approved by doctors at work & $78(18.5)$ & $152(36)$ & $134(31.8)$ & $58(13.7)$ \\
\hline
\end{tabular}




\begin{tabular}{|c|c|c|c|c|}
\hline $\begin{array}{l}\text { I can communicate with doctors at the work } \\
\text { environment }\end{array}$ & $76(18)$ & $102(24.2)$ & $167(39.6)$ & $77(18.2)$ \\
\hline $\begin{array}{l}\text { My job is effective for patients and their family } \\
\text { life }\end{array}$ & $150(35.5)$ & $149(35.3)$ & $102(24.2)$ & $21(5)$ \\
\hline $\begin{array}{l}\text { Support Services } \\
\text { I receive adequate support from support service } \\
\text { staff (meal, cleaning and care staff). }\end{array}$ & $139(32.9)$ & $96(22.7)$ & $150(35.5)$ & $37(8.8)$ \\
\hline $\begin{array}{l}\text { I have adequate materials and equipment for } \\
\text { patient care. }\end{array}$ & $106(25.1)$ & $123(29.1)$ & $105(24.9)$ & $88(20.9)$ \\
\hline I can give good quality patient care. & $99(23.5)$ & $87(20.6)$ & $151(35.8)$ & $85(20.1)$ \\
\hline $\begin{array}{l}\text { I receive qualified support from support services } \\
\text { staff (meal, cleaning and care staff }\end{array}$ & 84(19.9) & $88(20.9)$ & $115(27.3)$ & $135(32)$ \\
\hline
\end{tabular}

The table above reveals occupational stress among Nurses. More than half (52.6\%) of the respondents strongly disagree on society has positive opinion about nurses, $33.9 \%$ strongly disagree that institution gives professional opportunities, $38.9 \%$ agree that they communicate with other team members like Physiotherapist and respiration therapist, $36.5 \%$ agree that they receive support for in-service training and constant education, $29.1 \%$ agree that Nursing policies and procedures facilitates was their job, $29.6 \%$ agree that Safety provides a safe environment, $32.7 \%$ agree that they feel safe protected against damage (physical, moral, verbal), $34.1 \%$ agree that their shift work negatively affects my life and $35.5 \%$ disagree that they feel attached to work.

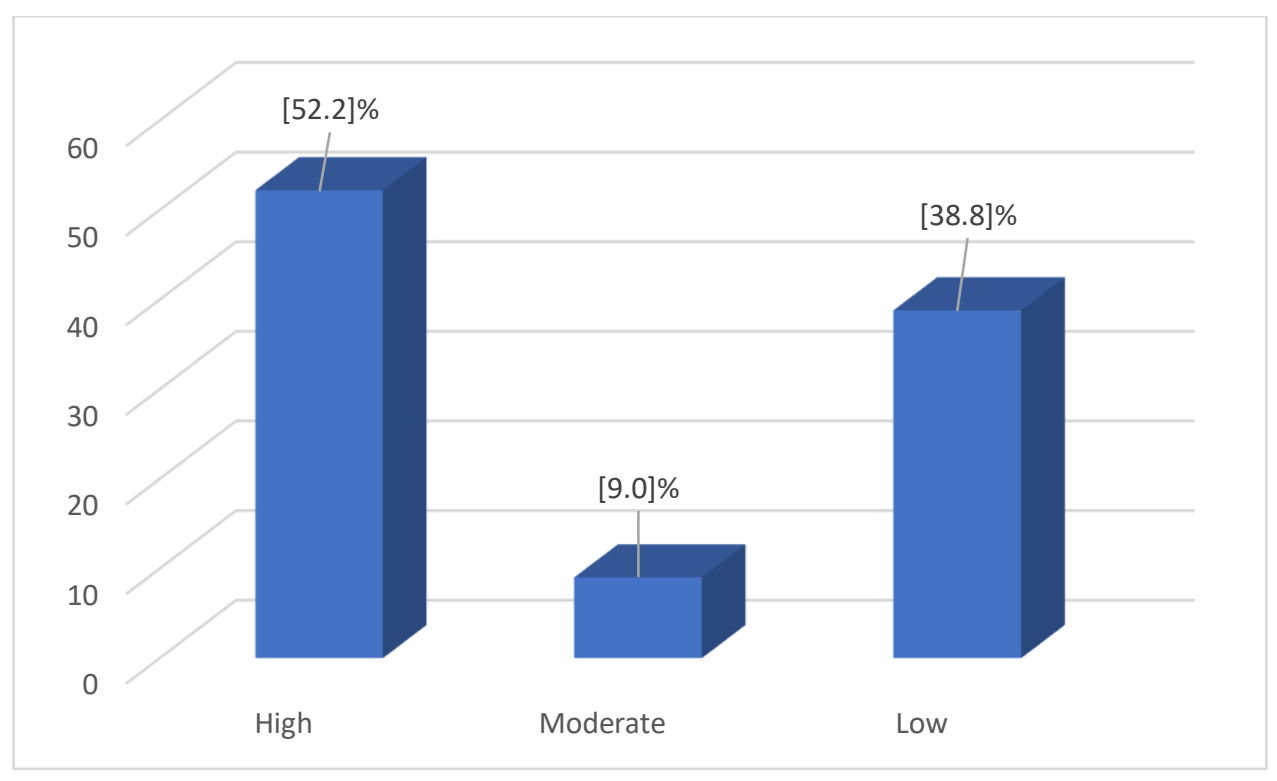

Figure 2: Summary of Work-related Quality of Life of Clinical Nurses 
The figure shows a summary of work-related quality of life scale. The result showed that more than half of the respondents $(52.2 \%)$ reported that the work-related quality of life was high, $38.8 \%$ rate as low and $9.0 \%$ moderate.

Table 5: Influence of Stress on Perceived Quality of Life among Nurses

\begin{tabular}{|l|l|l|l|l|}
\hline \multicolumn{1}{|c|}{ Variables (N=423) } & \multicolumn{1}{c|}{ SD } & \multicolumn{1}{c|}{ D } & \multicolumn{1}{c|}{ A } & \multicolumn{1}{c|}{ SA } \\
\hline Women are more affected than men & $104(24.6)$ & $63(14.9)$ & $84(19.9)$ & $171(40.5)$ \\
\hline Stress affects work output & $71(16.8)$ & $77(18.2)$ & $166(39.3)$ & $108(25.6)$ \\
\hline $\begin{array}{l}\text { Stress affects personal life such as relationship at } \\
\text { home }\end{array}$ & $59(14)$ & $76(18)$ & $206(48.8)$ & $81(19.2)$ \\
\hline Stress affects quality of care given to patients & $53(12.6)$ & $89(21.1)$ & $183(43.4)$ & $97(23)$ \\
\hline $\begin{array}{l}\text { Occupational stress is a recognized cause of } \\
\text { sickness absence among Nurses }\end{array}$ & $36(8.5)$ & $114(27)$ & $188(44.5)$ & $84(19.9)$ \\
\hline Stress adversely affect Nurses mental health & $27(6.4)$ & $114(27)$ & $168(39.8)$ & $113(26.8)$ \\
\hline Stress adversely affect Nurses physical health & $26(6.2)$ & $99(23.5)$ & $216(51.2)$ & $81(19.2)$ \\
\hline Stress affects leisure time & $23(5.5)$ & $94(22.3)$ & $183(43.4)$ & $122(28.9)$ \\
\hline Stress affects recreational activities & $26(6.2)$ & $84(19.9)$ & $163(38.6)$ & $149(35.3)$ \\
\hline Stress affects eating behaviour & $26(6.1)$ & $84(19.9)$ & $163(38.5)$ & $149(35.2)$ \\
\hline
\end{tabular}

The table above reveals stress on perceived quality of life among nurses. Majority $40.5 \%$ of the respondents strongly agreed women are more than men, 39.3\% agree that stress affects work output, $48.8 \%$ agreed that stress affected their personal life such as relationship at home, $43.3 \%$ agree that stress affects quality of care given to patients, $44.5 \%$ agreed occupational stress is a recognized cause of sickness absence among nurses, $39.8 \%$ agree that stress adversely affect nurses mental health, more than half of the respondents $51.2 \%$ agree that Stress adversely affect their physical health and $38.5 \%$ agree that stress affects their eating behaviour. 
Table 5: Summary of Multiple Regression Table Showing Joint and Independent Predictive Factors of Occupational Stress on Work Related Quality of Life

\begin{tabular}{|c|c|c|c|c|c|c|c|}
\hline \multirow[t]{2}{*}{ Model } & \multicolumn{2}{|c|}{$\begin{array}{c}\text { Unstandardized } \\
\text { Coefficients }\end{array}$} & \multirow{2}{*}{$\begin{array}{c}\begin{array}{c}\text { Standardized } \\
\text { Coefficients }\end{array} \\
\text { Beta }\end{array}$} & \multirow[t]{2}{*}{$\mathbf{t}$} & \multirow[t]{2}{*}{ Sig } & \multicolumn{2}{|c|}{$\begin{array}{c}\text { Confidence } \\
\text { interval }\end{array}$} \\
\hline & B & $\begin{array}{c}\text { Std.Err } \\
\text { or }\end{array}$ & & & & Upper & Lower \\
\hline Work Demands & 0.047 & 0.127 & 0.010 & .367 & 0.714 & -.203 & .296 \\
\hline $\begin{array}{l}\text { Work-Family } \\
\text { Conflict }\end{array}$ & -0.045 & 0.170 & -0.008 & -.267 & 0.789 & -.380 & .289 \\
\hline $\begin{array}{l}\text { Insufficient } \\
\text { Support from Co- } \\
\text { workers or } \\
\text { Caregivers }\end{array}$ & 0.265 & 0.159 & 0.047 & 1.665 & 0.097 & -.048 & .577 \\
\hline $\begin{array}{l}\text { Workplace } \\
\text { Violence and } \\
\text { Bullying }\end{array}$ & -0.025 & 0.167 & -0.004 & -0.148 & 0.882 & -.352 & .303 \\
\hline $\begin{array}{l}\text { Organizational } \\
\text { Issues }\end{array}$ & 0.369 & 0.174 & 0.065 & 2.116 & 0.035 & .026 & .711 \\
\hline $\begin{array}{l}\text { Occupational } \\
\text { Hazards }\end{array}$ & -0.183 & 0.158 & -0.034 & -2.158 & 0.024 & -.493 & .127 \\
\hline Difficulty Taking & -0.175 & 0.218 & -0.020 & -0.803 & 0.422 & -.604 & .254 \\
\hline Powerlessness & 0.174 & 0.171 & 0.029 & 1.017 & 0.310 & -.162 & .509 \\
\hline $\begin{array}{l}\text { Interpersonal } \\
\text { Relationships }\end{array}$ & 0.520 & 0.174 & 0.080 & 2.995 & 0.003 & .179 & .862 \\
\hline $\begin{array}{l}\text { Unmet Basic } \\
\text { Physiological } \\
\text { Needs }\end{array}$ & 0.345 & 0.176 & 0.067 & 3.697 & 0.005 & 0.235 & 0.972 \\
\hline $\begin{array}{l}\mathrm{R}=.926 \\
\mathrm{R}^{2}=.858 \\
F=22.210 \\
\mathrm{P}=0.001\end{array}$ & & & & & & & \\
\hline
\end{tabular}

From Table 5, the results indicate that, there was significant joint prediction of occupational stress (Work Demands, Work-Family Conflict, Insufficient Support from Co-workers or Caregivers, Workplace Violence and Bullying, Organizational Issues, Occupational Hazards, Difficulty Taking, Powerlessness, Interpersonal Relationships and Unmet Basic Physiological Needs) on work related quality of life $\left(\mathrm{R}^{2}=.85, \mathrm{~F}(11,410)=25.210, \mathrm{p}=0.01\right.$. The $R^{2}=.085$ indicates that the independent variables occupational stress (Work Demands, Work-Family Conflict, Insufficient Support from Co-workers or Caregivers, Workplace Violence and Bullying, Organizational Issues, Occupational Hazards, Difficulty Taking, Powerlessness, Interpersonal Relationships and Unmet Basic Physiological Needs) explained 85\% 
variation in dependent variable (work related quality of life). Furthermore, Organizational Issues $(\beta=0.06, t=2.11, p<.01)$, Occupational Hazards $(\beta=0.034$, $\mathrm{t}=2.15, \mathrm{p}<.01)$, Interpersonal Relationships $(\beta=0.080, \mathrm{t}=2.995, \mathrm{p}<.01)$, and Unmet Basic Physiological Needs $(\beta=0.067, \mathrm{t}=3.697, \mathrm{p}<.01)$ independently three of the variables (Organizational Issues, Occupational Hazards, Interpersonal Relationships and Unmet Basic Physiological Needs) predict the work-related quality of life.

\section{Discussion}

The study showed that majority of the respondent was between 30-49 years. Present study revealed substantial numbers of the respondents were highly stressed. More than one third lack support from the team affects patients' trust in me, $32.0 \%$ maintain professional units other than my own, above one quarter excessive duties in the workplace prevent me from attending to patients. This result can be attributed to the fact that those workers had been working in their functions for a long time in the institution, and thus had a higher control over the activity carried out. Affirm with the study carried out stress among nurses working in intensive care unit of Ittefaq Hospital Lahore in Pakistan by Salma et al., (2017). Major reason of stress is excessive workload which was believed by $65.2 \%$ of nurses to be a cause of stress. Similarly, shortage of staff was also a major source of stress. This supports the study conducted by Timothy et al., (2016) reported that majority of nurses who worked in the Medical/Surgical Department or ICU were more likely to have very high or high stress as compared to those who work in other departments. This present study supports the findings carried out at Salaga Government Hospital in Ghana where substantial number of nurses were face occupation stress due to number of hours in work place and short of staffs, affirm with the collaborating study of British Psychological Working Condition Survey, and the Nurse Stress Index where they found out that most of the nurse experienced high to extreme stress which lead to complete burnout, sickness and absences among nurses [21].

This present study identified factors responsible for stress among nurses; workload, prolong standing and no time for break, emotional load of dealing with aggressive and demanding patients and their families, shortage of staffs, lack of support/motivation from supervisors/ward managers, conflict with nurses and other medical staffs, unexpected death of patient, poor salary that cannot meet family demands, long hours of night shift, frequency of night shift, lack of resources and equipment are sources of stress. A similar study by Sarafis et al., (2016) identified discrimination, patient and family, unexpected death of patient, poor salary that cannot meet family demands. In previous study conducted among healthcare workers in Ugep, Yakurr local government area, Cross river state identified stressor as lack of support/motivation from supervisors/ward managers, conflict with nurses and other medical staffs, unexpected death of patient, poor salary that cannot meet family demands, long hours of night shift, Frequency night shift, lack of resources and equipment [22]. This present study is in line with the study of Ifeyinwa et al., 
2019 they found out that patients and their families, continual interaction, lack of cooperation and the nurse's sense of feeling unprepared to cope with their different emotional needs create feelings of anger, fear and disappointment in nursing staff. In the current survey, more than half of the respondents rate their work-related quality of life as good. Majority were not given professional opportunities, 38.9\% communicate with other team members, $36.5 \%$ receive support for in-service training and constant education, 29.6\% safety provides a safe environment. A similar study by Jovic-Vranes et al. in Serbia had revealed a low level of overall quality of life and job satisfaction in Serbian healthcare workers. This may be due to mostly young study population, fixed working hours of most of the study population, joint family type and most of them having two or less children. Ayers suggested that the job environment should motivate workers to perform at their best and show commitment to the organization, enhancing favourable work conditions to support the organization's mission and thus impacting on quality of life and job satisfaction. A study conducted among Staff Nurses in Selected Hospitals of Pune city in which their finding revealed that the level of quality of life was low [23,24]. This present study affirms with study of Sarafis et al., 2016 carried out research on the impact of occupational stress on Nurses' Caring Behaviours and their Healthrelated Quality of life were most of the respondents had a good quality of life.

\section{Conclusion}

Nurses are faced with variety of sources of occupational stressors. While investigating the predictors of quality of life among nurses, occupational stress remained a significant predictor of nurses' quality of life. Findings in this study showed that there is a relationship between occupational stress and perceived quality of life among nurses. Therefore, nurse educators and leaders should support nurses by conducting stress management training to reduce the impact of stress on their quality of life.

\section{Acknowledgment}

This paper was prepared in partial fulfilment of the requirements for the award of Bachelor of Nursing Science Degree (BNSc). The researchers appreciated the Management and Staff of Obafemi Awolowo University, Head and; the entire Staff of the Department of Nursing Science, clinical nurses in Ogun Sate and other stakeholders for successful completion of this study. 


\section{References}

[1] Permarupan, Y.P., Abdullah, A.M., Naresh, K.S., Roselina, A.S. and Naeem, H. (2020). Predicting Nurses Burnout through Quality of Work Life and Psychological Empowerment: A Study Towards Sustainable Healthcare Services in Malaysia. Sustainability journal; 2020. 12, 388

[2] Sook-Han, S., Won-Han, J. and Hyung-Kim, Y. (2018). Effect of Nurses' Emotional Labour on Customer Orientation and Service Delivery: The Mediating Effects of Work Engagement and Burnout. Saf. Health Work 2018, 9, 441-446.

[3] Feeley. N., Robins, S., Charbonneau, L., Genest, C., Lavigne, G. and LavoieTremblay, M. (2019). NICU Nurses' Stress and Work Environment in an Open Ward Compared to a Combined Pod and Single-Family Room Design. Adv. Neonat. Care 2019, 19, 416-424.

[4] Wang, Q.Q., Lv, W.J., Qian, R.L. and Zhang, Y.H. (2019). Job burnout and quality of working life among Chinese nurses: A cross-sectional study. J. Nurs. Manag. 2019, 27, 1835-1844.

[5] Jang, I., Kim, Y. and Kim, K. (2016). Professionalism and professional quality of life for oncology nurses. J. Clin. Nurs. 2016, 25, 2835-2845.

[6] Alghamdi, M.G. (2016). Nursing workload: A concept analysis. Journal of Nursing Management. 2016, 24, 449-457.

[7] Chuang, C.H, Tseng, P.C, Lin, C.Y, Lin, K.H. and Chen, Y.Y. (2016). Burnout in the intensive care unit professionals: A systematic review. Medicine (Baltimore) 2016, 95, e5629

[8] Blair-Loy, M., Hochschild, A., Pugh, A.J, Williams, J.C. and Hartmann, H. (2015). Stability and transformation in gender, work, and family: Insights from the second shift for the next quarter century. Community Work Fam. 2015, 18, 435-454.

[9] Kim, J.S. (2019). Emotional Labor Strategies, Stress, and Burnout among Hospital Nurses: A Path Analysis. J. Nurs. Scholarsh. 2019.

[10] Kwak, Y., Han, Y., Song, J.S. and Kim, J.S. (2019). Impact of emotional labour and workplace violence on professional quality of life among clinical nurses. Int. J Nurs. Pract. 2019, 10, e12792.

[11] Sarafis, P., Rousaki, E., Tsounis, A., Malliarou, M., Lahana, L. and Bamidis, P. (2016). The impact of occupational stress on nurses' caring behaviors and their health-related quality of life. BMC Nurs. 2016; 15(1):56.

[12] Dagget, T., Molla, A. and Belachew, T. (2016). Job related stress among nurses working in Jimma Zone public hospitals, South West Ethiopia: A cross sectional study. BMC Nurs.2016; 15(1): 39.

[13] Tiffany, W., Roger, H., Arthur, T. and Wilson, T. (2020). Global prevalence of burnout symptoms among nurses: A systematic review and meta-analysis. Journal of Psychiatry Research, Volume 123, April 2020, Page 9.

[14] Stephenson, J.O. (2020). Stress and abuse remain high among NHS nurses. Nursing Times. 2020 
[15] Gómez-Urquiza, J.L, De la Fuente-Solana, E.I. and Albendín-García, L. (2017). Prevalence of burnout syndrome in emergency nurses: a metaanalysis. Crit Care Nurse 2017;37: e1-9.

[16] Monsalve-Reyes, C.S., San Luis-Costas, C. and Gómez-Urquiza, J.L. (2018). Burnout syndrome and its prevalence in primary care nursing: a systematic review and meta-analysis. BMC Fam Pract 2018; 19:59.

[17] Tay, W.Y., Earnest, A., Tan, S.Y. and Ng, M.J. (2014). Prevalence of burnout among nurses in a community hospital in Singapore: a crosssectional study. Proc Singapore Health 2014; 23 (2):93-99.

[18] Nwozichi, C.U. and Ojewole, F.O. (2015). Potential stressors in cancer care: perceptions of oncology nurses in selected teaching hospitals in Southwest Nigeria. Afr J Med Health Sci 2015; 14:130-4.

[19] Henry, B.J. (2014). Nursing burnout interventions: what is being done? Clin J Oncol Nurs 2014; 18:211-4.

[20] Khamisa, N., Oldenburg, B., Peltzer, K. and Ilic, D. (2015). Work Related Stress, Burnout, Job Satisfaction and General Health of Nurses. International journal of environmental research and public health; 2015, 12(1): 652-666

[21] Kaburi, B.B., Fred, Y.B., Chrysantus, K., Donne, K.A., Ernest, K., Samuel, O.S. and Edwin, A.A. (2019). Psychological working conditions and predictors of occupational stress among nurses, Salaga Government Hospital, Ghana. The Pan African Medical Journal. 2019; 33:320.

[22] Etim, J.J., Bassey, P.E. and Ndep, A.O. (2015). Work-related stress among Healthcare Workers in Ugep, Yakurr Local Government Area, Cross River State, Nigeria: A Study of Sources, Effects, And Coping Strategies. International Journal of Public Health, Pharmacy and Pharmacology Vol.1, No.1, pp.23-34, July 2015.

[23] Kakade, S.N., Nandkumar, R.K. and Devi, L.B. (2016). The assessment of factors related to job stress and coping ability among staff nurses in selected hospitals of Pune city. International Journal of Science and Research, Volume 3 Issue 9; 2016.

[24] Sharon, G. and Cong, L. (2017). Work, Stress, Coping, and Stress Management. Organizational and Institutional Psychology. Oxford Research Encyclopaedia; 2017. 